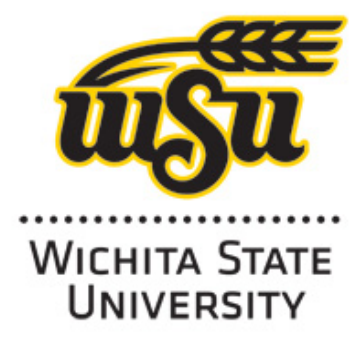

UNIVERSITY

\section{Wichita State University Libraries} SOAR: Shocker Open Access Repository

Gary H. Toops

Modern and Classical Languages and Literatures

\title{
Notes on Reflexivity and Causativity in Lithuanian
}

Gary H. Toops

Wichita State University no.1(Spring 1994), pp.53-62. DOI: 10.1080/01629779300000361 


\title{
NOTES ON REFLEXIVITY AND CAUSATIVITY IN LITHUANIAN
}

\author{
Gary H. Toops, The Wichita State University
}

This study concerns so-called "curative" (parüpinamàsis [veiksmäžodis]) ${ }^{1}$ or "passive causative" (neveikiamasis priežastinis [veiksmãžodis]) ${ }^{2}$ verbs derived from basic transitive verbs by means of the stem suffix - din, on the one hand, and the expression of identical causative meaning with non-causative verb forms, on the other; cf.:

(1) (a) (pa)situdinti kostiuma

'to have a suit made (sewn)'

(b) siudintis (pasisitudinti) kostiumg

'to have oneself a suit made (sewn)'

(c) sittitis (pasisiuti) kostiuma (pass siuveja, ateljeje)

'to have oneself a suit made (by a tailor, in a shop)'

(d) (pa)siuti kostiuma (pàs siuveja, ateljeje)

"to have a suit made (by a tailor, in a shop)" 3

In the examples above, (b) and (c) are synonymous (in the context provided by the spatial adverbial phrases pàs siuveja [literally] 'at a tailor's,' ateljejeje 'in a shop'). Examples (1)(a) and (d) are likewise synonymous. Examples (b) and (c) differ from (a) and (d) in that they are reflexive verb forms. The subjects of the reflexive verbs ${ }^{4}$ are semantically interpretable as expressing both Indirect Agent ("Causer") and Beneficiary. ${ }^{5}$ The reflexive verbs thus serve to convey here benefactive meaning and are synonymous with the corresponding nonreflexive verb forms used with the reflexive pronoun sáu in its ethical dative function, ${ }^{6}$ cf.:

(2) (a) Jônas siûdinasi kostiuma.

(b) Jönas sî́dina sau kostiuma.

'John is having himself a suit made ("sewn").'

(c) Jónas sìvasi kostiuma (pds siuveja).

(d) Jônas siuva sáu kostiuma (ateljeje).

'John is having himself a suit made ("sewn").'

In view of the above examples, I propose to discuss briefly three main questions. First, does reflexivization (i.e., "-si-affixation") of passive causatives result in the same syntactic and semantic changes observable in other ("nonpassive") causatives? Second, how is one to explain the use of non-causative verb forms for the expression of causative meaning? And third, why does Lithuanian tolerate, in most cases even prefer, in causative situations the use of non-causative verb forms, which are clearly ambiguous and subject to noncausative (mis)interpretation (i.e., Jónas siùva[si] kostiuma can be "literally" 
understood as Jōnas pats silivalsi] kostiuma "John himself is making ["sewing"] a suit $\left.{ }^{7}\right)$ ?

According to Jakaitiene, the stem suffix - din is simply a variant of another causative suffix, $-i n .^{8}$ Both suffixes, $-d i n$ and $-i n$, for example, occur with intransitive verb stems to form transitive verbs, $\mathrm{cf}$.:

(3) beginti (árkli) [< begti 'to run']

'to make/let (a horse) run'

(4) žéldinti (mišklis; pláukus) [< žélti 'to grow']

'to plant (a forest); grow (one's hair) / let (one's hair) grow'

According to Stang and Otrębski, -din was not originally a suffix in its own right: the $d$ was epenthetic and served to eliminate hiatus between a stem-final vowel and the suffix $-i n .{ }^{9}$ Because its original, phonologically conditioned function has been lost, synonymous pairs of transitive verbs exhibiting the suffixes $-i n$ and - din are not uncommon, cf.:

(5) lipinti $\sim$ lipdinti $(k \tilde{a})\left[<\right.$ lipti 'to stick'] ${ }^{10}$

'to glue, stick (something)' (i.e., 'to make [something] stick')

(6) sproginti $\sim$ sprogdinti $(k \tilde{a})[<$ sprogti to burst']

'to burst (something)' (i.e., 'to make [something] burst')

Apparently on the basis of such observations as these, Jakaitiene has concluded that curative, or passive causative, meaning is not an inherent property of the suffix -din. Instead, Jakaitiene points out that passive causative meaning is expressed only when the suffix is added to basic transitive verb stems. ${ }^{11}$ That is to say, if the suffix occurs with basic intransitive verb stems as in examples (3)-(6), the direct objects of the resulting causative verbs are Agents of the "underlying" caused action. If the same suffix occurs with transitive verbs, the resulting verb is a passive causative whose direct objects are Patients of the caused action, cf.:

(7) ausdinti (áudekla) [< austi 'to weave']

'to have (fabric) woven'

(8) dirbdinti (laivèli) [< dirbti 'to make']

'to have (a boat) made'

(9) statydinti (nâma) [< statýti 'to build']

'to have (a house) built'

Reasoning in this way, Jakaitiene maintains her thesis that -din and -in are, for the most part, arbitrary or, at best, lexically conditioned variants of one and the same causative morpheme. ${ }^{12}$ Her thesis, however, runs counter to Stang's observation, "[i]m Lit[auischen] hat sich der Typus auf -dina von demjenigen auf -ina losgerissen, und eine spezielle Funktion angenommen. Der Typus drickt aus, ,daß man et[was] durch einen anderen tun läßt...." ${ }^{* 13}$ In my opinion, Stang's observation is correct: the suffix -din did indeed "break away" from -in, at least partly. In speaking of -din, one must in fact distinguish between two homophonous suffixes: -din as an alternative to -in, as Jakaitiene proposes, on the one hand; and -din as a passive causative morpheme in its own right, on the other. My opinion is supported by cases like válgyti 'to eat' and valgydinti 'to feed, dine (someone); have (someone) eat,' cf.: 
(10) valgyti (duona)

'to eat (bread)'

(11) valgydinti (vaikus)

'to feed (the children)'

$V$ algyti is obviously a transitive verb. If Jakaitiene's thesis were correct, then the phrase valgydinti vaikus would have to signify 'to have the children eaten. ${ }^{14}$ The reason valgydinti ( $k \tilde{a})$ does not mean 'to have (something) eaten' is that the $d$ in the suffix is clearly performing its original hiatus-eliminating function and that the suffix is really -in (not the curative - din).

GeniuSienè has shown that reflexivization (-si-affixation) in Lithuanian, like reflexivization in the Slavic languages, is best defined as a derivational process involving valence reduction (predicate lowering). ${ }^{15}$ Causativity, on the other hand, involves an increase in the valence of a given basic verb (predicate raising). Passivization is also a valence-reducing process, but reflexivization differs from passivization in that passivization (given a basic transitive verb with accusative object governance) consistently entails omitting the Agent of a particular action and expressing the Patient of that action syntactically as subject rather than object. ${ }^{16}$ Reflexivization, in contrast, involves nothing more than valence reduction: the omitted participant (actant), from the viewpoint of the basic verb, may be either an Agent or a Patient. The semantic status of the remaining participant, expressed syntactically as the subject of the reflexive verb, is therefore ambiguous: it may be Agent, Patient, or a combination of the two. The verb derived through reflexivization accordingly expresses intransitive, passive, or reflexive meaning. Because Lithuanian reflexive verbs can govern accusative objects, the subjects of such verbs may also express Agent and Recipient (Beneficiary) simultaneously. "Benefactive" meaning is thereby expressed, cf.:

(12) Rātas sükasi. [< sükti 'to turn (trans.)']

Intransitive: 'The wheel turns.'

(13) Daüg dionos susivalge. [ $<$ suvalgyti 'to eat']

Resultative passive: 17 'Much bread was eaten.'

(14) Jónas skitasi. [< skisti 'to shave (tranis.)']

Patientive (accusative) reflexive: 'John is shaving (i.e., himself),'

(15) (a) Jōnas skùtasi bar̃zda.

"Benefactive" (dative) reflexive: 'John is shaving his beard. ${ }^{18}$

(b) Motina siuvasi suknèle. [< situi 'to sew']

"Benefactive" (dative) reflexive: 'Mother is sewing herself a dress.'

As Geniusiene has shown, reflexivization of (derived) causative verbs clearly entails valence reduction, ${ }^{19}$ assuming specifically a "decausative" ${ }^{120}$ or "anticausative"21 function. For example, from the basic intransitive ("monovalent") verb sugesti 'to break (down), the transitive ("divalent"22) verb sugadinti 'to break, damage' is formed by means of the causative suffix -in. According to Geniusiene, affixing the reflexive particle -si- to sugadinti reduces the valence of the causative by one actant, thereby producing another "monovalent" 
verb-susigadint - which is virtually synonymous with the basic verb sugesti, ${ }^{23}$ cf.:

(16)(a) Sugêdo laikrodis. 'The clock broke.'

(b) Sugadinaũ laikrodi. 'I broke the clock.'

(i.e., 'I made the clock break.')

(c) Susigadino laikrodis. 'The clock broke.'

If reflexivization of a transitive verb derived through causative suffixation yields an intransitive verb that is synonymous with the basic intransitive verb, one might expect that reflexivization of a curative verb derived through causative suffixation of a basic tansitive verb would likewise yield a synonym of the basic verb. This is not the case, however; cf.:

(17) sugèst $\rightarrow \rightarrow$ sugadinti $\rightarrow$ susigadinti $=$ sugèsti 'to break'

(18) pasiliti $\rightarrow$ pasitudinti $\rightarrow$ pasisitudinti $\neq$ pasiuti 'to sew'

Reflexive forms of curative verbs, in fact, express only (accusative or dative) "reflexive" meaning, in the traditional sense of the term, ${ }^{24} \mathrm{cf}$.:

(19)(a) nusikirpdinti ${ }^{25}$ 'to have one's hair cut' (cf. [14] above)

(b) nusikiripdinti plákkus 'to have one's hair cut' (cf. [15(a)] above)

(c) pasistatýdinti nãma ( = pastatýdinti sáu nãma) 'to have a house built: for oneself' (cf. [15(b)] above)

As example (19)(c) and my earlier examples (2)(b) and (d) demonstrate, benefactive meaning can also be expressed (in ernphatic or contrastive contexts) by means of the non-reflexive verb form and the dative reflexive pronoun. However, where "accusative reflexive" meaning is expressed, i.e., where the subject of the reflexive verb simultaneously functions as (Indirect) Agent and Patient (rather than as Agent and Recipient), the non-reflexive verb with the accusativg feflexive pronoun save is inadmissible, cf.:

(20) (*ukirpdinti save 'to have one's hair cut'

In conttrast, inon-curative verbs formed from basic intransitive verbs by means of causative suffixation exhibit no constraint on the occurrence of the accusative reflexive pronoun, $c f$ ::

(21)(a) gýdyti (ligonii) [< gýti 'to convalesce; heal (intrans:)']

'to treat/heal (a patient)'

(b) gydytis 'to treat/heal oneself'

(c) gydyti save 'to treat/heal oneself'

However, if the verb gydytis (like situtis in [1(c)]) is used instead in the curative sense 'to have oneself treated'-i.t., as the equivalent of an unambiguously curative form gýdydintis ${ }^{27}$-then the occurrence of the reflexive pronoun save with the non-reflexive verb form is in fact precluded. Thus, even in the contrastive context The neighbor is having himself and his son treated at the hospital, the reflexive pronoun savè cannot be used, cf.:

(22)(a) *Kaimýnas gýdo save ir stunu ligónineje. Instead, the verb gýdyti must occur twice-once in its reflexive form, and again in its non-reflexive form, cf.:

(22)(b) Kaimýnas gýdosi ir gýdo sûnu ligóninèje. 
(Literally) "The neighbor is having himself treated and is having his son treated at the hospital. ${ }^{28}$

Interestingly, the same constraint on the occurrence of the reflexive pronoun with what Nedjalkov has called "contextual causatives" (Russian kontekstnye kauzativy $)^{29}$ is observable also in the Slavic languages. ${ }^{30}$

Both morphological and syntactic reflexivization of passive causatives thus clearly differs from that of non-passive causatives. As we have seen in the case of gydyti(s), however, non-passive causatives do share with passive causatives the same constraint on the co-occurrence of the reflexive pronoun in those instances where the non-passive causative is apparently re-analyzed as a basic transitive verb that can be used in a passive causative sense. (In other words, the accusative reflexive pronoun cannot be coreferential with a subject expressing the Indirect Agent of an action, regardless whether the subject actually governs a morphologically curative verb or not.)

How do formally non-curative verbs come to be used as curatives? Geniusiene, in discussing the various meanings attributable to the process of reflexivization, mentions the existence of "causative reflexives." ${ }^{131}$ These are verbs which, though formally non-causative (non-curative), acquire passive causative meaning in certain contexts. They exist not only in Lithuanian, but in Latvian and the Slavic languages as well, cf.:

(23) Lithuanian: gydytis (pds speciallsta); krikštytis

Latvian: ärsteties (pie specialista); kristïties

Russian: lecit'sja ( $u$ specialista); krestit' sja 'to have oneself treated

(by a specialist)'; 'to have oneself christened'

As Endzelins has stated, "both in the Baltic and Slavic languages, reflexive forms have developed in place of the original middle forms. ${ }^{+12}$ Margulies and Isacenko similarly likened the use of reflexive verb forms in Slavic to the use of middle verb forms in classical Greek. ${ }^{33}$ Indeed, Liddell and Scott provide unambiguously causative definitions for numerous middle verb forms, among

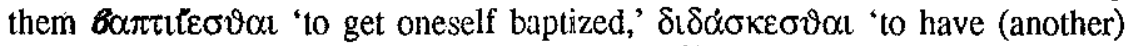
taught,' $\delta \mathrm{u} \alpha \zeta \varepsilon \sigma \vartheta \alpha \mathrm{l}$ 'to have one's case tried.'24 As Benveniste has noted, the original voice opposition in Greek was active vs. middle, with special forms for the passive (in the future and aorist tenses only) eventually evolving from the middle. ${ }^{35}$ This suggests that the subject of an active verb form was semantically marked for Direct Agency, while the subject of a middle (or rather, "non-active") verb form was not so marked. Thus, the subject of such verbs could function as Agent, as Patient, and as Agent and Patient or Recipient simultaneously-just as the subjects of the Lithuanian rellexive verbs cited in examples (12)-(15). One should not, however, overlook the fact that the concept of Agency (or "Agentivity"36) is itself ambiguous: Agency may be Direct or Indirect. Agents are called Indirect if they "indirectly," i.e., through the medium of another (Direct) Agent, perform a particular action. That is to say, they cause a particular action to be performed. In view of the fact that the subjects of Lithuanian reflexive verbs are semantically ambiguous in ways strikingly similar to those in which the subjects of Greek middle verbs are, I propose that the curative 
meaning which these verbs may express is due to the ability of their subjects to function as Indirect Agents. For this reason, non-curative verb forms can frequently be used to convey curative meaning.

Unfortunately, the foregoing observations do not adequately explain the use of non-reflexive, non-curative verb forms like (pa)situi kostiuma (pds siuveja, ateljeje) in example (1)(d). Given the fact that the accusative reflexive pronoun cannot be used with formally non-curative verbs used in curative contexts, I hypothesize that the use of non-reflexive verbs was originally patterned after the curative use of reflexive verbs. That is to say, if gydytis can signify 'to have oneself treated,' i.e., if it can express reflexive curativity, then the use of $g y d y t i$ for the expression of non-reflexive curalivity ('to have [someone] treated') would seem to be a logical syntactico-semantic development. If this analysis is correct, then the inadmissibility of * gydyti save in the sense 'to have oneself treated' may be explained by stating that gydytis, being primary, already sufficed for the expression of reflexive curative meaning.

With regard to curative -din-suffixed verbs, Stang states: ,Derartige passive Kausativa' können zu allen möglichen Verba gebildet werden. ${ }^{37}$ Indeed, F. Kurschat's Litauisch-deutsches Wörterbuch lists - din-suffixed passive and nonpassive causative forms for practically every one of its transitive and intransitive verb entries. ${ }^{38}$ A. Kurschat, in his posthumously published four-volume Litauisch-deutsches Wörterbuch, followed for the most part his uncle's example. ${ }^{39}$ These observations suggest that curative verb formation by means of - din-suffixation is a sufficiently productive derivational process to make the expression of curative meaning by way of non-curative verb forms in Lithuanian rather superfluous. By this I mean that it seems somewhat incongruous that one might ambiguously state Jonas siluvasi kostiuma (literally) 'John is sewing himself a suit,' when what one actually means is Jönas siudinasi kostiuma 'John is having a suit sewn for himself.' Indeed, Senn's Handbuch der litauischen Sprache even hints that "contextual causativity" (i.e., the use of non-curative verb forms in a curative sense) is a Slavic influence. Among the German translations of the Lithuanian preposition $p d s$, Senn cites the German gloss von and precedes this with the word "Slavismus" in parentheses. ${ }^{40}$ Actually, Lithuanian pds corresponds almost exactly to the Russian (Polish, Czech, Slovak) preposition $u$ (German bei, French chez). In the Slavic languages, however, this preposition is also used to convey the Direct Agent of a contextually implied caused action. ${ }^{41}$ Thus, the causative (curative) situation denoted by "The neighbor is having his son treated by the doctor' is expressed in Russian as Sosed lečit syna u vrača. The literal Lithuanian translation of the Russian conveys exactly the same curative meaning. It is only in such contexts, then, that Lithuanian pas could ever be functionally equivalent to German von, cf.:

(24) Kaimýnas gýdo sünu pàs gýdytoja.

'Der Nachbar läßit den Sohn vom Arzt behandeln.'

In actual fact, however, curative verb formation through -din-suffixation is not as productive as non-native Lithuanian scholars have, it would seem, previously assumed. In response to queries regarding curative verbs-specifically, 
gydydinti 'to have (someone) treated' (< gydyti 'to treat, heal') and (nu)fotografuodinti 'to have (someone) photographed' (< fotografúoti 'to photograph') - one informant stated: "Most of them are theoretically imaginable but sound extremely artificial and are never used in any living Lithuanian dialect ... [including] standard Lithuanian." ${ }^{\text {.42 }}$ In view of the numerous curative forms cited in F. Kurschat's Wörterbuch, however, this same informant conceded that "there is a possibility that such forms were used in the Lithuanian dialect of East Prussia (which died out in the 19th century)." Nevertheless, as early as 1913, Jablonskis, in reviewing K. Jaunius's Lietuvos kalbos gramatika (sic; St. Petersburg, 1911), agreed with the author that F. Kurschat's causatives (curatives?) bègdinu 'laufen lassen,' gyvéndinu 'wohnen lassen,' stovédinu 'stehen lassen,' "practically speaking, can in no way exist in a living dialect [žmoniu kalboje 'human language']." ${ }^{143}$ Unfortunately, the twenty-volume Lithuanian Academy Dictionary is unreliable on this score, since numerous -dinsuffixed verb entries appear to have been copied directly from F. Kurschat's Wörterbuch, and their usage, unlike that of the Academy Dictionary's other verb entries, is not illustrated by any attested literary source. ${ }^{44}$

In sum, morphological and contextual causativity in Lithuanian, as far as I have been able to determine, remains an unsolved problem, on which my foregoing notes, I would hope, have nevertheless shed some additional light.

\section{ENDNOTES}

1. See E. Jakaitienè, "Deverbatyviniai dabartinès lietuviu kalbos veiksmažodžiai su priesaga -inti," Baltistica 4 (1968):2, 228, and Jan Otrębski, Gramatyka jezyka litewskiego. 2: Nauka o budowie wyrazów (Warsaw: Paŕstwowe Wydawnictwo Naukowe, 1965), 411.

2. See Jakaitiené, "Deverbatyviniai," 228, and Christian S. Stang, Vergleichende Grammatik der baltischen Sprachen (Oslo et al.: Universitetsforlaget, 1966), 374. Alfred Senn, Handbuch der litauischen Sprache. 1: Grammatik (Heidelberg: Carl Winter, 1966), 260, uses the term "resultative causative," although earlier in his Kleine litauische Sprachlehre (Heidelberg: Julius Groos, 1929), 236, he uses the term "passive causative" as well.

3. See Bronius Piesarskas and Bronius Svecevicius, Lietuvil-anglu kalbu žodynas (Vilnius: Mokslas, 1979), 648 and 541.

4. I use the term "reflexive verb" in its "traditional sense" (as also, for example, Alexander M. Schenker, "W sprawie sie raz jeszcze," Jezyk Polski 65 [1985]:1, 9-23), although the term "-si-affixed verb" is doubtless more accurate. In this respect I depart here from my preference for the term "-sjasuffixed" with respect to Russian verbs (see Gary H. Toops, Grammatical Causativity in Slavic [Ph.D. dissertation: Yale University, 1985]).

5. Emma Geniušiené, "Die Reflexivverben des Litauischen im Vergleich zu denen des Lettischen, Russischen und Deutschen," Zeitschrift für Slawistik 23 (1978): 5, 660, uses the term Rezipient 'Recipient' and refers to such reflexive verbs as Rezipientenreflexiva. 
6. See Geniušiené, "Die Reflexivverben," 661-662.

7. See Emma Geniušiené [È. Š. Genjušene], "K teorii opisanija refleksivnyx glagolov (na materiale litovskogo jazyka)" in V. S. Xrakovskij, ed., Zalogovye konstrukcii v raznostrukturnyx jazykax (Leningrad: Nauka, 1981), 176-177.

8. Jakaitiené, "Deverbatyviniai," 228, and E. Jakaitiene, "Dèl lietuviụ kalbos veiksmažodžiı priesagu," Baltistica 6 (1970): 2, 175.

9. Stang, Vergleichende Grammatik, 374, and Otrębski, Gramatyka, 413. According to Stang, loc. cit., the $d$ has retained its original hiatus-eliminating function in Latvian.

10. One should not overlook the fact that in addition to the suffixes -in (lipinti) and -din (lipdinti), the suffixes $-y$ (lipyti) and -dy (lipdyti) may likewise occur with the same function as -in and -din (the meaning of all four verbs is identical).

11. Jakaitiené, "Dèl...priesagu," 175.

12. Ibid.

13. Christian S. Stang, Das slavische und baltische Verbum (Skrifter utgitt av det Norske Videnskaps-Akademi 2: Historisk-Filosofisk klasse 1 [1942], 1-280). Stang quotes here K. Brugmann, Grundriß der vergleichenden Grammatik der indogermanischen Sprachen (Strasboury, 1897-1916), II²:3 §233.

14. There are several other cursory, but nonetheless compelling, observations which support the proposition that curative and non-curative -din are actually two distinct, albeit homophonous, suffixes. First, as Otrębski, Gramatyka, 412 , points out, the curative suffix - din hardly ever alters the accentuation of the basic (non-suffixed transitive) verb (although, ironically, Otrębski, in providing examples of a few exceptions to this general rule, erroneously cites the non-curative verb valgydinti). Second, curative verbs are almost exclusively formed by means of -din-suffixation; this is not the case with other causative verbs (see note 10). In my admittedly limited research, I have encountered only two curative verbs that do not have the suffix -din: silidyti (kä) 'to have (something) sewn' (see Lietuvos TSR Mokslu Akademija. Lietuviụ kalbos ir literatũros institutas, Lietuviu kalbos žodynas [Vilnius: Mokslas, 1981], XII, 590) and kirpinti(s) 'to have (something/one's hair) cut' (see Lietuvos TSR Mokslu Akademija. Lietuviu kalbos ir literatūros institutas, Lietuvilı kalbos žodynas [Vilnius: Valstybine Politines ir Mokslinès Literatūros Leidykla, 1959], Y, 849). However, situdinti and kirpdinti(s) also exist, and the fact that the stressed syllables of the former verbs are identical to those of the basic verbs situti 'to sew' and kirpti 'to cut' cannot be ignored. Finally, curative verbs can be formed from almost any transitive verb by means of the suffix -din; this does not hold true for other suffixes. According to one informant (Tomas Venclova, Yale University, personal communication), newly formed curative verbs are technically "acceptable," although they may strike the native speaker of Lithuanian as being "artificial." 
15. GeniuSienè, "Die Reflexivverben," 657ff. For similar views on reflexivization in Slavic languages, see: Leonard H. Babby, "The Relation Between Causative and Voice: Russian vs. Turkish," Wiener slawistischer Almanach 11 (1983), 61-88; Helmut Faßke, "Wo gramatiskej funkciji t.mj. refleksiwnych słowjesow," Lètopis Instituta za serbski ludospyt Rjad A 28 (1981): 4, 1-12; and Schenker, "W sprawie sie raz jeszcze."

16. This description of passivization is, of course, slightly simplified. In Lithuanian, objectless intransitive verbs can also be passivized. This results in impersonal passive constructions where the Agent of the original nonpassive verb, if expressed, occurs in the genitive case, in the same way as Agents are "re-introduced" into passive constructions from which they have originally been eliminated (see Toops, Grammatical Causativity in Slavic ). Thus, Kds čid bavo? 'Who was here?' can be passivized: Kienó cia bata? (literally) *'By whom is been here?' (sic). German has similar impersonal passives (Hier wurde viel getanzt [literally] *'Here was [being] danced a lot'). In German passive constructions, moreover, the Patient of an action does not govern the verb as subject if the "original" active verb form has dative object governance. Thus, passivization of $\mathrm{Er}$ hat mir geholfen 'He helped me' results in Mir ist (von ihm) geholfen worden 'I was helped (by him),' not *Ich bin (von ihm) geholfen worden.

17. The term "resultative passive" is taken here from Geniusiené, "Die Reflexivverben," 665 .

18. GeniuSiené, "Die Reflexivverben," 660-661, classifies such verbs as "possessive Patiensreflexiva" and distinguishes them from the benefactive reflexives ("Rezipientenreflexiva"). I group the two together here partly for convenience and partly because similar dative reflexive constructions perform both functions in other languages, cf. French and German: se faire la barbe, sich den Bart rasieren; se faire une robe, sich ein Kleid machen.

19. Geniusiene, "Die Reflexivverben," 657.

20. GeniuSiene, "K teorii opisanija refleksivnyx glagolov," $171 \mathrm{ff}$.

21. Babby, "The Relation Between Causative and Voice," 72.

22. The terms "monovalent," "divalent," etc., are adopted here from Lucien Tesnière, Éléments de syntaxe structurale (Paris: Klincksieck, 1959), $261 \mathrm{ff.}$

23. Geniưsiené, "Die Reflexivverben," 657; Karl Horst Schmidt, "Zur Syntax des Kausativums im Georgischen und in indogermanischen Sprachen," Bedi Kartlisa 21/22 (1966), 121-127, speaks in terms of "one-, two-membered sentences" (ein-, zweigliedrige Säize). His calculation of "members" is equivalent to Tesnière's valence +1 (i.e., number of actants + verb).

24. Admittedly, one could also imagine a context in which a reflexive passive causative is used in a "resultative passive" sense (see note 17): Daüg suknëliu pasisitudino, meaning something like "A lot of dresses were ordered (and "gotten") sewn.'

25. Lietuviu kalbos žodynas, XII, 1149.

26. Lietuviu kalbos zoodynas, V, 848. 
27. See Alexander Kurschat, Litauisch-deutsches Wörterbuch (Göttingen: Vandenhoek und Ruprecht, 1968-1973 [4 vols.]), 589.

28. Actually, a truly literal translation would be "The neighbor is treating himself and is treating (his) son at the hospital,'

29. V. P. Nedjalkov, Kauzativnye konstrukcii y nemeckom jazyke. Analitičeskij kauzativ (Leningrad: Nauka, 1971), 20.

30. See Toops, Grammatical Causativity in Slavic, $86 \mathrm{ff}$.

31. Gieniưienè, "Die Reflexivverben," 665-666.

32. Jānis Endzelins, Comparative Phonology and Morphology of the Baltic Languages (Slavic Printings and Reprintings, 85. W. R. Schmalstieg and B. Jēgers, trans. The Hague-Paris: Mouton, 1971), 247.

33. Alfons Marguliés, Die Verba reflexiva in den slavischen Sprachen (Heidelberg: Carl Winter, 1924), 204, and Alexander V. IsaCenko, Die russische Sprache der Gegenwart. 1: Formenlehre (Halle [Saale]: Max Niemeyer, 1962), 460.

34. Henry G. Liddell and Robert Scott, comps., An Intermediate Greek-English Lexicon, founded upon the seventh edition of Liddell and Scott's GreekEnglish Lexicon (Oxford: Oxford University Press, 1972), 146, 198, 202.

35. Émile Benveniste, "Active and Middle Voice in the Verb" in his Problems in General Linguistics (Miami Linguistics Series, 8. M. E. Meek, trans. Coral Gables: University of Miami Press, 1971), 145-152.

36. Babby, "The Relation Between Causative and Voice," 82.

37. Stang, Das slavische und baltische Verbum, 187.

38. Friedrich Kurschat, Wörterbuch der litauischen Sprache. 2: Litauischdeutsches Wörterbuch (Halle [Saale]: Verlag der Buchhandlung des Waisenhauses, 1883).

39. A. Kurschat, Litauisch-deutsches Wörterbuch.

40. Senn, Handbuch, 418.

41. See Babby, "The Relation Between Causative and Voice," $75 \mathrm{ff}$.

42. Tomas Venclova (Yale University, personal communication).

43. Jonas Jablonskis, "Kun. Kazimiero Jauniaus Lietuvos kalbos gramatika (1913)" in his Rinktiniai raštai (J. Palionis, ed. Vilnius: Valstybiné ir Mokslines Literatūros Leidykla, 1959), vol. 2, 128.

44. Consider, for example, skarmaliuodinti in Lietuviu kalbos žodynas ("Lithuanian Academy Dictionary"), XII, 759. This verb is apparently taken directly from F. Kurschat's Litauisch-deutsches Wörterbuch, 378, where it is defined as "lumpig einhergehen lassen" (to let [someone] go about [looking] ragged'). Even though the Lithuanian Academy Dictionary cites the basic verb as skarmaliuoti (F. Kurschat, Litauisch-deutsches Wörterbuch, 378, cites skarmalititi 'mit Lumpen bekleidet schnell gehen, gehen, daß die Lumpen fliegen' ['to walk fast while dressed in rags; to walk so fast that the rags fly']), it does not provide a corresponding -din-suffixed verb form with the expected accent, viz. skarmaliuodinti (see, however, A. Kurschat, Litauisch-deutsches Wörterbuch, 2173). 